URPO HARVAN

TÄRKEIN PANOS OLI

KÄSITTEIDEN MÄÄRTTELY.

\title{
Tampereen
}

\section{aikuiskasvatuksen koulukunnan loistava menneisyys}

\author{
$y$ \\ Tampereen yliopiston aikuiskasvatustutkimuksen vaiheet hahmottuvat \\ koulukunta-käsitteen ja aikuiskasvatuksen professorivaalien kautta. \\ Miksi Tampereen koulukunnaksi ristitty tiedeorientaatio hajosi
} ja mitä siitä seurasi?

TAMPEREEN YLIOPISTON aikuiskasvatuksen tutkimuksella on pitkät, aina 1930-luvulle saakka ulottuvat juuret, joiden maaperä oli Helsingin Yhteiskunnallisessa Korkeakoulussa. Sen tutkijat Zachris Castrén ja Urpo Harva loivat kirjoituksillaan tiedeorientaation, joka on ainakin jossain muodossa säilynyt 2010-luvulle saakka. 'Koulukunnan' käsitettä (Suoranta \& Kauppila 2006, 23; Paloheimo 1979, 1-3) voidaan käyttää, koska siihen luokiteltavien tutkijoiden mielenkiinto on suuntautunut pääosin vapaan sivistystyön tutkimukseen, heidän käsityksensä aikuiskasvatuksesta tieteenä on ollut samanlainen, ja koska Castrén ja Harva saivat seuraajia tulevien vuosikymmenten mittaan.

Aikuiskasvatuksen tutkimuksella oli Tampereella 1980-luvulle asti valtakunnallisesti tietynlainen monopoli, koska vasta vuonna 1983 myös Helsingin yliopistoon perustettiin aikuiskasvatuksen professuuri. Juha Suorannan ja Juha Kauppilan mukaan kyseessä oli aikuiskasvatustutkimuksen toinen vaihe. Kolma vaihe seurasi 1990-luvulla, jolloin perustettiin uusia aikuiskasvatuksen professuureja Turun, Jyväskylän, Joensuun ja Lapin yliopistoihin sekä Åbo Akademin Vaasan-yksikköön. (Suoranta \& Kauppila 2006, 23.) Miksi Tampereen koulukunnaksi ristitty tiedeorientaatio lopulta hajosi, ja mitä siitä seurasi? Tarkastelen Tampereen yliopiston aikuiskasvatustutkimuksen vaiheita koulukunta-käsitteen ja aikuiskasvatuksen professorivaalien kautta hakemalla vastausta eri lähteistä. Aineistona ovat esimerkiks Tampereen yliopiston eri hallintoelinten, erityisest tieteenalan viranhaltijoiden valintaprosessia koskevat pöytäkirjat, tutkijahaastattelut ja aihepiiriä taustoittava kirjallisuus. Näkökulmaani määrittää työura aikuiskasvatuksen ja aikuiskoulutuksen parissa opettajana, rehtorina ja sivistysjärjestön toiminnanjohtajana. Lähestyn aihetta sekä kasvatustieteilijänä että historiantutkijana.
CASTRÉN JA HARVA LOIVAT PERUSTAN

Mikä oli Zachris Castrénin ja Urpo Harvan tiedeorientaatio eli tutkimuksen suunta ja käsitys aikuiskasvatuksesta tieteenä?

Yhteiskunnallisen Korkeakoulun ensimmäistä kansansivistysopin opettajaa ja Helsingin työväenopiston johtajaa Castrénia ei aina ole pidetty tiedemiehenä, mutta hänen kirjallinen tuotantonsa on kiistatta teoreettisuudessaan korkeatasoista. Harvan assistenttina toiminut Erkki Karjalainen nimittää Vapaan sivistystyön historia -teoksessaan Castrénin kirjoituksia "pienimuotoisiksi tutkielmiksi" (Karjalainen 1970, 247). Niissä käsiteltiin 1900-luvun alun työväenopistojen perustehtävää ja opetusta. Castrén toteaa, että "yliopistollisessa hengessä opiskelijan on pyrittävä perinpohjaisuuteen ja hankittava itselleen selvyyttä tieteen edellytyksistä”. (Ks. Wuorenrinn \& Kosonen 1949.)

Castrénia voidaankin pitää yhtenä ensimmäisistä vapaan sivistystyön peruskäsitteiden kehittäjistä, mikä ennen kaikkea oikeuttaa hänen asemansa myöhemmässä aikuiskasvatustutkimuksessa.

Myös Urpo Harva aloitti tieteellisen työnsä Yhteiskunnallisen Korkeakoulun opettajana, kuitenkin jo päätoimisena. Hänen uransa jatkui Tampereen yliopiston kansansivistysopin ja viimein aikuiskasvatuksen ensimmäisenä professorina. Harvan tärkein panos kehittymässä olleelle aikuiskasvatustieteelle oli vapaata sivistystyötä käsittelevät lukuisat kirjoitukset mutta myös käsitteiden määrittely uuri Harva otti käyttöön käsitteen 'aikuiskasvatus' samannimisessä teoksessaan, joka ilmestyi vuonn 1955. Muutkin, 'aikuiskasvatukseen' läheisesti liittyvät käsitteet määritellään perusteellisesti Harvan tuotannossa: esimerkiksi' 'kansansivistäjä', 'kansansivistys,' 'ihmisen kasvu', 'sivistys' ja 'kasvatustiede' Kari Kantasalmen mukaan Harva kehitti kansan-
Sivistajasta aikuiskasvattajan teoreettisen konstruktion jo 1950-luvulla. (Kantasalmi 2014, 254-255.)

Harva itse ei ollut Tampereen yliopiston emeritus professorin Tuomiston mukaan (Tuomisto 2017) suuri empiirisen tutkimuksen edistäjä, päinvastoin tämä metodinen suuntaus oli hänen puutteensa. Silti hän korosti kirjoituksissaan, että "vain empiirisen tutkimuksen avulla voidaan osoittaa, onko mahdollista saada aikuisessa ihmisessä aikaan kasvatuksen kautta kokonaismuutos". (Harva 1955, 10-15.)

Aikuiskasvatuksen tiedeyhteys oli Harvalle selvästi osa kasvatustiedettä, vaikka organisatorinen linkk olikin yhteiskuntatieteisiin. Harvan seuraajat Jukk Tuomisto ja Aulis Alanen korostavat hänen tiedeorientaationsa keskeistä piirrettä, joka oli "filosofisyhteiskuntatieteellinen" ja humanismiin nojaava. (Ks. Tuomisto 1997, 10-11; Alanen 1997, 27-36.) Huomattava on myös jo Harvalla esiintynyt elinikäisen kasvatuksen ja oppimisen käsite.

Tampereen yliopistossa Harvan professorivuosien 1965-1973 opinnäytteiden teemat liittyivät lähe yksinomaan vapaaseen sivistystyöhön. Aihealueen suuri suosio on merkille pantavaa: esimerkiksi lukuvuosina 1971-1972 hyväksyttiin peräti 111 pro gradu -tutkielmaa (Jokinen 2017, 43). Määrää selittää se, että vapaan sivistystyön oppilaitoskenttä oli tuolloi suurin ja yhtenäisin aikuiskoulutuksen muoto. Tuomiston mukaan tiede ponnistaa aina käytännöstä. (Tuomisto 1985, 170-171.)

AIKUISKASVATUSTUTKIMUKSEN KAHTIAJAKO - MATTI PELTONEN PROFESSORIKSI

Aikuiskasvatuksen professuurin täyttö Urpo Harva jälkeen osoittautui kasvatustieteelliselle tiedekunnale vaikeaksi tehtäväksi. Kun valinta viimein vuonn 1977 tehtiin, lopputulosta voi pitää aiemmin syntyneen koulukunnan kannalta lähes katastrofina. Aineiston perusteella näet tiedekunnassa jo pitkään nimenomaan aikuiskasvatuksen tutkijana toiminut apulaisprofessori Aulis Alanen syriäytettiin virantäytössä tiedepoliittisen pelin seurauksena. Muodollinen ja sinänsä kiistämätön peruste oli se, että opintokerhotyötä käsitelleen väitöskirjansa lisäksi Alase la ei ollut muuta samantasoista tutkimusta. 
Matti Peltoselle vapaA

SIVISTYSTYÖ OLI T T̈̈YSIN

VIERAS TUTKIMUSALUE.

Huomionarvoista on kuitenkin se, että Alasen työtä vuosien 1971 ja 1975 Aikuiskoulutuskomiteoiden pääsihteerinä ei virkaa täytettäessä noteerattu lainkaan. (TAY 1977a.)

Matti Peltosen valintaa perusteltiin hänen "tehokkaalla tutkimustyöllään" ja "vakuuttavilla tieteellisillä ansioillaan aikuiskasvatuksen professorin virkaan". (TAY 1977a.)

Tampereen yliopiston elinikäisen oppimisen ja kasvatuksen tutkimuksen professorin Anja Heikkisen mukaan valitsijat tunsivat Peltosen hyvin saman viiteryhmän perusteella. Heikkinen katsookin, että nimenomaan Peltonen haluttiin virkaan, ei Alasta (Heikkinen 2017). Myös Jukka Tuomiston mukaan Alanen syrjäytettiin vaalissa "kyseenalaisin perustein". (Tuomisto 2014, 210.)

Peltosen valinnan arvioinnissa pitää kuitenkin ottaa huomioon 1970-luvun Aikuiskoulutuskomitean mietintöjen I ja II ja yhteiskunnallisen kehityksen myötä tapahtunut suuri koulutuspoliittinen muutos. Komitean esitykset merkitsivät myös käytännössä ammatillisen aikuiskoulutuksen vahvaa esiin nostamista sekä tutkimuksessa että koulutuspolitiikassa. Vapaa sivistystyö ei enää ollut aikuiskasvatustutkimuksen pääkohde. Kielenkäytössä aikuiskasvatuksesta tuli aikuiskoulutusta. Urpo Harvan opit eivät enää kiinnostaneet opiskelijoita.

Uutta ennakoivat myös professorin vaalissa annetut lausunnot: "Aikuiskasvatus on osa kasvatustiedettä, ja sen tutkimuskohteena on yhä enemmän työelämässä tapahtuva ammatillinen aikuiskoulutus." (TAY 1975). Peltonen jakoi tämän käsityksen.

Peltoselle vapaa sivistystyö oli täysin vieras tutkimusalue, samoin aikuiskasvatus vielä valintavaiheessa. Vaalista tehdyssä valituksessaan Alanen osoitti, että "Peltosen kohdalla asiantuntijat ovat lukeneet aikuiskasvatuksen alaan teoksia, jotka eivät sinne kuulu lainkaan”. (TAY 1977b.)
Professorinakin Peltosen tiedeorientaatio liittyi mmattikasvatuksen teemoihin. Tutkimusta oli hänen mielestään tehtävä niin, että se hyödytti käytäntöä teoriat eivät olleet niin tärkeitä. Niinpä hän julkaisuissaan useimmiten nojautui teorian osalta muiden kirjoituksiin (Honka 2017). Aikuiskasvatuksesta Peltonen kirjoitti professorina lähinnä aikuisten opiskelua ja oppimista koskevia sitaattiteoksia, kuten vuonna 1980 ilmestyneen Aikuisten opiskelutaidon

Professorin vaali ja sitä koskeneet valitukset johtivat siihen, että Tampereen yliopiston aikuiskasvatustutkimus jakaantui kahteen leiriin, jotka eivät juuri seurustelleet keskenään. Leiriytyminen jatkui aina 2010-luvulle saakka.

Matti Peltonen ei kauan viihtynytkään professorina. Hän lähti silloisen Suomen Työnantajien Keskusliiton (STK) koulutusjohtajaksi vuonna 1984. Toki hänen professuurinsa aikana kasvatustieteiden tiedekunnassa oli muitakin ansioituneita nimenomaan aikuiskasvatuksen tutkijoita. Jukka Tuomisto piti yllä Harvan tiedeorientaatiota muun muassa jatkamalla tämän käsiteanalyysejä ja kirjoittamalla tämän tuotannosta. Tuomiston aikalaisista silloinen lehtori, sittemmin professori Eero Pantzar loi tiedekunnassa oman aikuiskasvatuksen tutkimuspolkunsa.

Vielä 1980-luvun alussa Tampereen yliopisto oli selvästi merkittävin aikuiskasvatuksen tutkimuksen tuottaja maassa. Se näkyi muun muassa siinä, että $A i$ kuiskasvatus-lehdessä julkaistujen artikkeleiden määristä tamperelaisten osuus oli peräti 60 prosenttia. (Vanttaja 1999, 73-91.)

\section{MYÖHÄÄN PROFESSORIKS}

\section{- VIIMEIN AULIS ALASEN VUORO}

o ennen Aulis Alasen valintaa aikuiskasvatuksen professoriksi koulutuspolitiikassa mentiin kohti kysyntäpainotteista aikuiskoulutusta, jota pidettiin koko yhteiskunnan rakenteellisen muutoksen välineenä. Jatkuvan koulutuksen periaatteesta rakennettiin koko kansan koulutusstrategian ydintä. Aikuiskasvatus oppiaineena oli menettänyt suosiotaan muille tieteenaloille. Keskeinen käsitteellinen konteksti alkoi olla elinikäinen oppiminen, joka oli yliopistonlehtori Karin Filanderin mukaan "puheessa kaikkialla”. (Filander 2012, 140. .)
Aulis Alasen valinta aikuiskasvatuksen professoriksi vuonna 1986 oli eräänlainen lohdutuspalkinto, niin pitkään hän oli vuoroaan odottanut. Aikuiskoulutuksen maailma ja yliopistot olivat muuttuneet Alaselle myönteiseen suuntaan, ja hänen ansionsa erityisesti aikuiskasvatuksen tutkijana tunnustettiin. Asiantuntijalausunnossa Alasen sijoittuminen Tampereen yliopiston perinteeseen eli Urpo Harvan koulukuntaan, todettiin nyt vain tosiasiana, ei haittana. Samassa lausunnossa kuitenkin korostettiin, että "aikuiskasvatus tieteenhaarana tutkii yhä voimakkaammin ammatillista aikuiskoulutusta”. (TAY 1985)

Alasen pitkäaikainen työtoveri ja "hengenheimolainen" Jukka Tuomisto on nähnyt entisen esimiehensä keskeisiksi tutkijanansioiksi ”aikuiskasvatuksen tutkimuksen ja teorian muodostuksen syventämisen". Alanen oli "suoraan Harvan aloittaman humanistisen linjan jatkaja". (Tuomisto 2006, 7-12.)

Suurin merkitys alan tutkimukselle oli Alasen 'elinikäisen kasvatuksen' käsitteen kehittämisessä. Samannimisestä, yhdessä Juha Sihvosen kanssa tuotetusta teoksesta (Alanen \& Sihvonen 1983) tuli klassikko.

Alasen tutkimustoiminta suuntautui jatkossakin enemmän vapaaseen sivistystyöhön (ks. esim. Sivistysjärjestöjen tehtäväkuvan muutos 1986), vaikka mmatillinen aikuiskoulutus ei ollut hänelle vierasta. Esimerkistä käy aikuiskasvatuksen yleisteos, ja oppikirjaksikin hyväksytty Suomen aikuiskasvatuksen organisaatiomuodot vuodelta 1992

Professori Alasen ja apulaisprofessori Tuomiston samanlainen tiedeorientaatio pohjusti saumatont yhteistyötä tamperelaisessa aikuiskasvatustutkimuksessa. Koulukunta oli tass voimissaan.

ANNIKKI JÄRVINEN AIKUISKASVATUKSEN, ERITYISESTI AMMATILLISEN AIKUISKOULUTUKSEN PROFESSORIKSI

Aulis Alasen jäätyä eläkkeelle vuonna 1991 seurasi taas pitkä välivaihe Tampereen yliopiston aikuiskasvatuksen professuurin hoidossa, sillä virka täytettiin vasta vuonna 1998. Laitoksen aikuiskasvatukseen orientoituneet tutkijat, muun muassa Jukka Tuomisto, Eero Pantzar, Rainer Aaltonen, Raimo Jaakkola Esa Poikela, Annikki Järvinen, Arto Juhela, Anja Heik- kinen ja Marjo Vuorikoski julkaisivat tutkimuksia, joista suurin osa koski työelämää. Tuomisto jatkoi Alasen elinikäisen oppimisen tutkimussuuntaa ja työelämän tutkimusta, kun taas Pantzar suuntautui muun muassa informaatioyhteiskunnan ja verkkopedagogiikan tutkimukseen. Vain Tuomiston voi katsoa selvästi edustaneen Harvan perintöä ja koulukuntaa.

Professorin viran täytön tultua tiedekuntaneuvostoon neuvosto päättikin yllä̈täen äänestyksen jälkeen muuttaa nimikettä: virka olisi määräaikainen "aikuiskasvatuksen, erityisesti ammatillisen aikuiskoulutuksen" professuuri. Tiedekunta perusteli päätöstään viittaamalla "työelämän ja ammatillisen aikuiskoulutuksen asettamiin vaatimuksiin". (TAY 1996.)

Virkaa hakeneet olivat pääosin "omasta talosta", loppumetreillä Järvinen ja Tuomisto. Asiantuntijalausunnoissa korostettiin professuurin tehtäväalan mukaisesti työelämää koskevan tutkimuksen merkitystä valinnassa. Niinpä Järvisen vahvuutena pidettiin hänen "suhteellisen johdonmukaista julkaisulinjansa, joka on laajenemassa oppilaitoksista työelämän organisaatioihin". (TAY 1996.$)$

Marjo Vuorikoski arvioi jälkeenpäin, että Tuomistoa pidettiin enemmän perinteisen tiedeorientaation edustajana, mitä ei enää pidetty ansiona. Ulospäin neuvosto korosti Järvisen kansainvälisiä meriittejä sivuuttaen Tuomiston tässä. (Vuorikoski 2017.)

Tampereen yliopiston aikuiskasvatuksen tutkimus jakaantui jälleen selvästi eri tiedeorientaatioihin. Työssä oppimisen tutkimusta edustanut Järvinen itse kuvaa suuntaa "elinikäisen oppimisen paradigman operationalisoimiseksi ja työssä tapahtuvaa kasvua tukevaksi". Hänen mukaansa tuloksena oli työssä oppimisen kokemuksellinen prosessimalli. (Annikki Järvisen jäähyväisluento Tampereen yliopistossa; Järvinen 2017a.) Muistion ja julkaisuluettelon perusteella Järvisen tiedeorientaatio oli varsin kaukana Harvan perinteestä.

Järvisen saavutuksia olivat suuret Suomen Akatemian hankkeet, joihin hän keräsi ympärilleen muita tutkijoita, esimerkiksi Esa Poikelan. Pääteema oli "työ ja koulutus muutoksessa”. Toinen tärkeä alue oli kansainvälinen yhteistyö ja sitä koskevat seminaarit. Aikuiskasvatuksen kotipesän tieteenä Järvinen näki olevan ”aidosti monitieteisessä yksikössä eikä lasten ja nuorten kasvatukseen fokusoivassa kasvatustieteiden tiedekunnassa”, 
Tultaessa 2000-luvulle Tampereen yliopiston kasvatustieteiden opinnäytetöiden ylivoimainen enemmistö voidaan luokitella ammatillisen aikuiskoulutuksen piiriin kuuluviksi. Esimerkiksi vuonna 2003 näitä pro gradu -tutkielmia oli 12, kun yleiseen aikuiskasvatukseen kuuluvia oli neliä, mutta vapaan sivistystyön graduja ei yhtäkään. (Jokinen 2017, 140.)

\section{JUHA SUORANTA PROFESSORIKSI}

\section{YLEISELLÄ TOIMENKUVALLA}

Annikki Järvinen jäi eläkkeelle vuonna 2005, vaikka oli saanut viisivuotiskauteensa pidennyksen. Kun kasvatustieteiden tiedekunnan laitosneuvosto käsitteli viran auki julistamista, esille nousi uudelleen sen tehtäväala. Jälleen äänestettiin asiasta, ja nyt enemmistö oli "laaja-alaisen" aikuiskasvatuksen professuurin kannalla. Laitosneuvoston puheenjohtajana tuolloin toimineen Eero Pantzarin mukaan "ehkä tiedekunnan sisällä elänyt vanha aikuiskasvatuksen koulukunta iski nyt takaisin". Katsottiin myös, että ammatillisen koulutuksen professoreita, kuten Pekka Ruohotie, oli jo riittävästi. (Pantzar 2017.)

Professorin viran tehtäväalaa ei ollut rajattu, mikä vaikutti sekä hakijoihin että asiantuntijalausuntoihin niin, että mikään hakijoiden tiedeorientaatio ei ollut ensisijainen kriteeri. Niinpä asiantuntijalausunnoissa painotettiin hyvinkin erilaisia meriittejä. Tasaveroisina hakijoina pidettiin Eero Pantzaria ja Juha Suorantaa, jonka kannalle asiantuntijoiden enemmistö asettui. Tiedekuntaneuvosto teki hänestä ehdollepanon, jonka yliopiston rehtori vahvisti.

Suorannan ansioina pidettiin ennen kaikkea perehtymistä kansainvälisiin kysymyksiin, globalisaatioon ja mediakasvatukseen. Yhden arvion mukaan "Suoranta keskustelee tutkijana suurista kysymyksistä". Esiin nostettiin myös hänen perehtymisensä "sivistyshistorialliseen tutkimukseen". (TAY 2004.)

Miksi tälläkään kertaa Tampereen yliopiston pitkäaikainen aikuiskasvatuksen tutkija, tässä tapauksessa Eero Pantzar, ei tullut valituksi? Tiedekuntaneuvoston kokoonpano antaa osviittaa. Neuvoston puheenjohtaja Tuomas Takala ei ollut suopea aikuiskasvatukselle, joten Pantzar "vanhan koulun" edustajana oli huonossa asemassa. Kättä kollegan puolesta ei nostanut myöskään Jukka Tuomisto. On ilmeistä, että kun Pantzar ei ollut suuntautunut vapaan sivistystyön tutkimukseen - Suoranta taas siinä vaiheessa oli - piti Tuomisto viimeksi mainittua parempana vaihtoehtona.

Professorina Suoranta asemoi itsensä heti alkuun niin, että mitään aikuiskasvatuksen koulukuntaa ollut Tampereella koskaan ollutkaan. Hän sanoi, ett "aikuiskasvatustutkimuksen tila ja olemus oli Tampereella melko selkiytymätön tullessani Tampereelle, joten ajatus jostakin koulukunnasta on liian vahva; etsikkoaika menetettiin, kun professuuria ei saatu pitkään aikaan täytettyä Aulis Alasen jälkeen”. (Suoranta 2017a.) Samoin Tampereella pitkään tutkijan toiminut Esa Poikela arvioi, että tamperelainen tutkimus oli jo asemansa menettänyt Suorannan astuess virkaansa. (Poikela 2017.)

Suorannan suhde vapaaseen sivistystyöhön on ollut ristiriitainen. Yhtäältä hän esimerkiksi julkaisi jo 2000-luvun alussa yhdessä Petri Salon kanssa teoksen Sivistyksellinen aikuiskasvatus (2002). Toisaalt hän muistelee, että "en hakeutunut Tampereen yliopistoon vapaan sivistystyön tutkimuksen vuoksi". (Suoranta 2017a.)

Mihin Suoranta on professorina tutkimuksessaan suuntautunut? Hän vastaa näin: "Minulle läheisin tutkijaverkosto on koostunut kriittisen yhteiskuntatieteen edustajista ja heidän mukanaan kriittisen ja radikaalin aikuiskasvatuksen sekä kasvatustieteilijöiden laajasta kansainvälisestä joukosta." (Suoranta 2017a.)

Tekstistä tulee esiin uuden aikuiskasvatuksen proessorin täysin toisenlainen tiedeorientaatio, joka jäleen kerran poikkesi aiemmasta traditiosta, ja varsinkin koulukunnasta. Kun Suoranta - aika yllättäen - vuonna 2013 yliopiston rehtorin päätöksellä siirrettiin kasvatustieteiden tiedekunnasta yhteiskuntatieteiden puolelle, hän erottautui vieläkin enemmän muista tieteenalan tutkijoista. (Heikkinen 2017; Tuomisto 2017.)

Suoranta on tehnyt niukasti yhteistyötä vanhan tiedekuntansa kanssa. Taustalla on hänen käsityksensä aikuiskasvatuksen tiedeyhteydestä, jolle on ominaista kriittinen suhtautuminen kasvatustieteiden tiedekuntaan ja varsinkin sen opettajankoulutukseen jota hän on pitänyt vieraana aikuiskasvatukselle.

Vieläkö Tampereen aikuiskasvatuksen koulukuntaa on olemassa? Kokonaan se ei ole sentään hävinnyt Varsinkin professori Anja Heikkinen on pitänyt perinnettä yllä yhdessä muutamien nuorten tutkijakoululaisten kanssa joissakin vapaan sivistystyön hankkeissa. Samoin lehtori Karin Filander lukeutuu osittain koulukuntaan. Dekaani Risto Honkonen korosta että tiedekunnan strategiassa elinikäisen oppimisen ja kasvatuksen osuus on merkittävä. (Honkonen 2017) Tätä kautta Harvan koulukunta hengittää edelleen.

Kokoavana vastauksena kysymykseen Tampereen koulukunnan vaiheista voidaan todeta, että se hajosi yliopiston kasvatustieteiden tiedekunnan aikuiskasvatuksen professorin vaalissa vuonna 1977 , nousi uudelleen vuodesta 1986 alkaen, mutta hajaantui uudelleen 1990-luvun lopulla jälleen professorin vaalissa.

Ammatillisen aikuiskoulutuksen voimakas esintulo 1970-luvulta lähtien on itsestäänselvästi vaikuttanut Tampereen koulukuntaan. Toinen taustatekijä on

Näkökulma perustuu teokseen Jokinen, J. (2017). Tampereen koulukunnan synty ja hajoaminen. 2010-luvulle. Helsinki: Vapaa sivistystyö VST r.y.

\section{ARKISTOLÄHTEET}

TAY (1974-2015) Tampereen yliopiston kasvatustieteellisen tiedekunnan tiedekuntaneuvoston pöytäkirjat 1974 2015.

TAY (1975) Tampereen yliopiston kasvatustieteiden tiedekunnan tiedekuntaneuvoston pöytäkiria 29.4.1975. TAY (1977a) Tampereen yliopisto, kasvatustieteiden tiedekunnan tiedekuntaneuvoston pöytäkirja 22. AY (1977b) Tampereen yliopiston kasvatustieteiden tiedekunnan tiedekuntaneuvoston pöytäkirja 6.8.1977.

TAY (1985) Tampereen yliopiston kasvatustieteiden tiedekunnan tiedekuntaneuvoston pöytäkirja 7.11.1985.

MUISTIOT

Jonkonen R. (2017) Sähköpostimuistio muistio kirjoittajalle 5.9.2017.

Jarvinen A. (2017a). Sähköpostimuistio kirjoittajalle 8.3.2017 suuri muutos yliopistoissa: Tampereen yliopistossa ei ole enää professuureja eikä oppiaineita, vaan kaikki on liikkeessä, niin professorit kuin muutkin tutkijat Dekaani joutuu sovittelemaan erilaisten paineiden ristitulessa, jossa aikuiskasvatuksen tutkimus on vain osa suurta kokonaisuutta. Ulkopuolisen tutkijan näkökulmasta kuitenkin väitän, että ratkaisu siirtää aikuiskasvatuksen professori eri tiedekuntaan irralleen kasvatustieteista vuonna 2013 ei ollut idea linen pa

Koko suomalainen aikuiskasvatuksen tutkimus on hajallaan eri yliopistoissa ja muissa tutkimuslaitoksissa. Yhtenäisyyteen pyritään, mutta se voi oll toteutumaton haave (AITURI 2011)

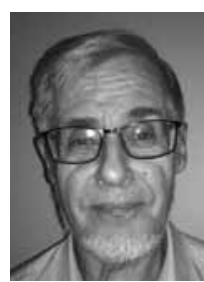

YRKI JOKINEN

KT, VTT, vapaa tutkija
Suoranta J. (2017a). Sähköpostimuistio kirjoittajalle 21.8.2017

Vuorkoski M. (2017). Sähköpostimuistio kirjoittajalle 31.52017
(1992-2015). Tampereen yliopiston pöytäkirjat 1992-2015.

TAY (1996) Tampereen yliopiston kasvatustieteiden tiedekunnan tiedekuntaneuvoston pöytäkirja The 8.12 .2004

TAY (2013) Tampereen yliopiston rehtorin päätökset 2013. 
SUULLISET LÄHTEET

Kallimo, K. (2016). Perusturvan toimialajohtaja. Jyväskylän kaupunki. Haastattelu 15.4.2016.

Filander, K. (2017). Karin Filander. Yliopistonlehtori.

Tampereen yliopisto. Haastattelu 3.5.2017.

Heikkinen, A. (2017). Anja Heikkinen. Professori.

Tampereen yliopisto. Haastattelu 24.5.2017.

Järvinen, A. (2017b). Annikki Järvinen. Professori emerita Haastattelu 10.3.2017.

Honka, J. (2017). Juhani Honka. FT. Haastattelu 30.1.2017.

KIRJALLISUUS

Alanen, A. (1983). Elinikäisen kasvatuksen käsite. Teoksessa Alanen A. \& Sihvonen J. (toim.) Elinikäinen kasvatus. Helsinki: Gaudeamus, 14-26.

Alanen, A. (1992). Suomen aikuiskasvatuksen organisaatiomuodot. Opetusmonisteet B 7. Tampere: Tampereen yliopisto.

Filander, K. (2012). Discursive turns from 'Bildung' to managerialism. Memory-work of the Finnish adult education generations. European Journal for Research on the Education and Learning of Adults, RELA 3 (2), 135-153.

Harva, U. (1946). Kansansivistys. Helsinki: Otava. Harva, U. (1958). Aikuiskasvatus. Helsinki: Otava.

Jokinen, J. ( 2017). Tampereen koulukunnan synty ja hajoaminen. Aikuiskasvatuksen tiedeorientaatioita 930-luvulta 2010-Iuvulle. Helsinki: Vapaa sivistystyö VST ry.

Kantasalmi K. \& Nest M. (2014). Johdanto. Valistuksesta elinikäiseen oppimiseen. Teoksessa Kantasalmi, K. \& Nest, M. (toim.). Valistajia, sivistajlia, poliitikkoja ja asiantuntijoita: näkökulmia aikuiskasvatuksen kentän vaikuttajiin. Tampere: Tampere University Press, 233-270.

Karjalainen, E. (1970). Suomen vapaan kansansivistystyön vaiheet. Helsinki: Weilin + Göös.

Paloheimo, H. (1979). Tiedepolitiikan koulukunnat. Politologian tutkimuksen ja sosiologian laitos. N:o 36 Turku: Turun yliopisto.

Peltonen, M. (1969). Oppilasarvostelun häiriöistä. Acta Universitatis Tamperensis ser A 28. Tampere: Tampereen yliopisto.

MUUT

AITURI (2011). Aikuiskasvatuksen tutkimusyhteistyön rakenteelliset innovaatiot. Hanke. https://www. alkuiskasvatuksentutkimusseura fir tutkimus/aituri-hanke-2010-2011/(31.10.2018)
Pantzar, E. (2017). Eero Pantzar. Professori emeritus. Haastattelu 20.5.2017

Poikela, E. (2017). Esa Poikela. Professori emeritus. Haastattelu 21.10.2017.

Suoranta, J. (2017b). Juha Suoranta. Professori. Tampereen yliopisto. Haastattelu 15.8.2017.

Tuomisto, J. (2017). Jukka Tuomisto. Professori emeritus Haastattelu 24.5.2017.

\section{Päätoimittajat paneelissa}

Kriittisyys, tieteellisyys ja uteliaisuus ovat arvoja, joihin Aikuiskasvatuksen nykyinen ja tuleva päätoimittaja nojaavat.

Peltonen, M. (1981). Aikuisdidaktiikan perusaineksia. Helsinki: Werner Söderström Oy.

Sihvonen, J. (1996). Sivistystä kaikille vai valituille. Acta Universitatis Tamperensis. ser A vol. 519. Tampere: Tampereen yliopisto.

Suoranta, J. (2006). Aikuiskasvatuksen tieteellistyminen Teoksessa Suoranta J. \& Kauppila J. (toim.). Aikuiskasvatuksen risteysasemalla. Julkaisusarja B. Oppimateriaaleja n:o 23. Joensuu: Joensuu yliopiston täydennyskoulutuskeskus, 21-40.

Tuomisto, J. (1985). Aikuiskasvatuksen kehittymisestã käytäntönä, oppiaineena ja tieteenä. Teoksessa Manni E. \& Tuomisto J. (toim.). Humanistin teemojen tuntumassa. Tampere: Tampereen yliopisto, 171-197.

Tuomisto, J. (2006). Esipuhe. Teoksessa Tuomisto J \& Salo P. (toim.). Edistävä ja viihdyttävä aikuiskasvatus. Tampere: Tampere University Press, 7-11.

Tuomisto, J. (2014). Suunnittelukeskeisen aikuiskoulutuspolitiikan arkkitehdit. Teoksessa Kantasalmi, K. \& Nest, M. (toim.). Valistajia, sivistäjï̈, ikkoja ja asiantuntijoita. Tampere: Tampere ess, 305-340

Vanttaja, M. (1993). Aikuiskasvatuksen tutkimus Suomessa. Aikuiskasvatuksen historian muotoutuminen ja tutkimusten painopisteet vuosin 1970-1990. Pro gradu -tutkielma. Turku: Turun yliopisto.

Wuorenrinne, T. I. \& Kosonen, V. (1949). Zachris Castrén Kansansivistäjä ajatustensa valossa. Helsinki: Otava.
AIKUISKASVATUS ON TIETEENALANSA AINOA VERTAISARVIOITU TIEDELEHTI. MIHIN SITA TARVITAAN?

Heikki Silvennoinen (HS): Koulutuksen ja oppimisen kysymykset kaikkineen ovat muodostuneet entistä tärkeämmäksi tutkimuskohteeksi. Tiedelehti osaltaan pitää alan tutkimusta elinvoimaisena ja tarjoaa kiinnekohdan tutkijoille. Se voi nostaa merkittäviä aiheita yleisempäänkin tietoisuuteen ja keskusteluun.

Ulpukka Isopahkala-Bouret (UI-B): Aikuiskasvatuksen tavoite on olla alansa tutkimuksen edelläkävijä ja edistää tutkimukseen perustuvaa ymmärrystä koulutuksesta, oppimisesta ja kehittämisestä aikuiselämän erilaisissa ympäristöissä. Se mahdollistaa tieteellisen vuoropuheluun, jolloin voi syntyä ymmärrystä yksittäisiä tutkimuksia laajemmista ilmiöistä.

AIKUISKASVATUSTA OPETETAAN JA TUTKITAAN SEITSEMÄSSÄ YLIOPISTOSSA. MILLAINEN SUHDE TIEDELEHDELLÄ ON TIETEENALAAN?

UI-B: Eri yliopistoissa syntyy hieman eri suuntiin haarautuvia määritelmiä aikuiskasvatuksesta. Jos ne saadaan kohtaamaan Aikuiskasvatuksessa, lehdellä on mahdollisuus laajentaa alan toimijoiden itseymmärrystä omasta alasta ja omasta paikasta kentällä.

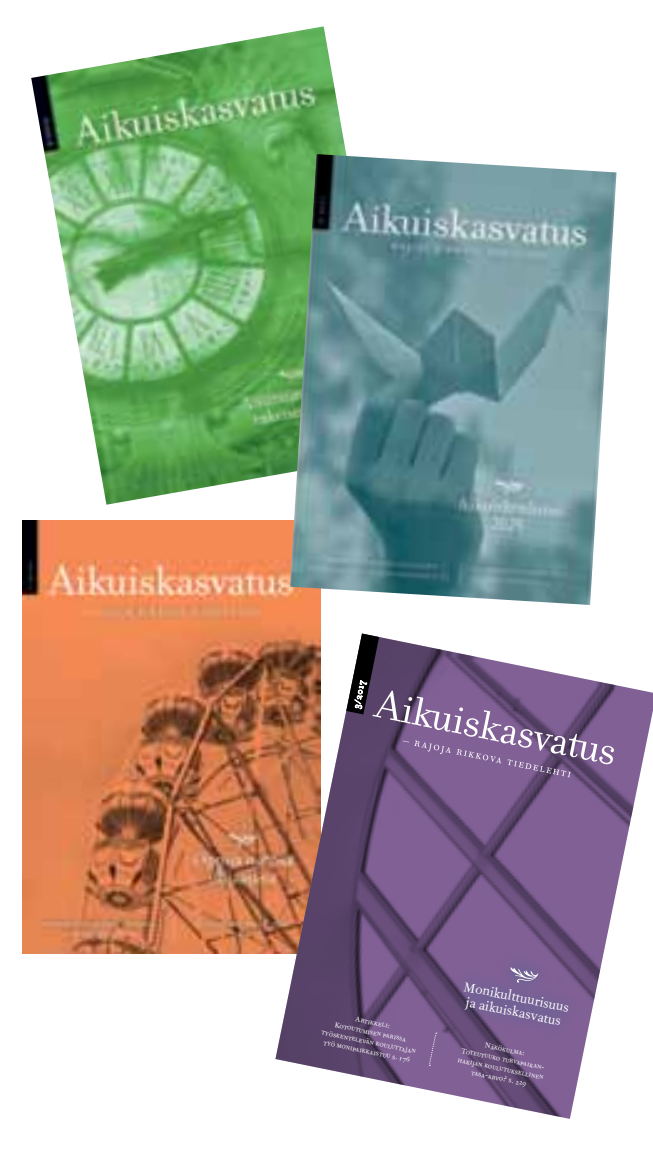

Heikki Silvennoisen päätoimittamia Aikuiskasvatuksen numeroita vuosilta 2010-2018. 